\title{
Paid work, unpaid work, and economic viability in alternative food initiatives: Reflections from three Boston urban agriculture endeavors
}

\author{
Carole Biewener* \\ Simmons College
}

Submitted September 22, 2015 / Revised January 28 and February 25, 2016 /

Accepted February 25, 2016 / Published online March 21, 2016

Citation: Biewener, C. (2016). Paid work, unpaid work, and economic viability in alternative food initiatives: Reflections from three Boston urban agriculture endeavors. Journal of Agriculture, Food Systems, and Community Development, 6(2), 35-53. http://dx.doi.org/10.5304/jafscd.2016.062.019

Copyright (C) 2016 by New Leaf Associates, Inc.

\begin{abstract}
This article addresses issues related to paid work, unpaid work, and economic viability in alternative food initiatives (AFIs) by comparing three urban agriculture entities in Boston, Massachusetts, U.S. The discussion is framed in terms of what constitutes alternative economic practices. Three standards of assessment are used in the analysis: First, that of whether the AFIs are able to provide "good jobs" along with "good food"; second, the extent to which the AFIs engage in alternative economic practices by relying on non-exploitative forms of work; and third, the extent to which they foster spaces for enabling progressive social change by engaging in a reflexive local politics oriented toward creating sustainable, democratic, and
\end{abstract}

\footnotetext{
* Carole Biewener, Professor of Economics and Women's and Gender Studies, Simmons College; 300 The Fenway; Boston, Massachusetts 02115 USA; biewener@simmons.edu
}

equitable community food systems. Preliminary research indicates that the three AFIs surveyed represent a spectrum with respect to their ability to provide "good jobs," their non-exploitative economic practices, and the extent to which they foster spaces for enabling a reflexive food politics. Given that the economic viability of all three AFIs depends on a significant amount of unpaid work, the discussion concludes by reflecting on the nature and implications of unpaid work by addressing three questions: How is unpaid work understood and fostered by these AFIs; what are the conditions that enable it; and is it indicative of alternative, noncapitalist economic logics and practices?

\section{Keywords}

alternative food initiatives, food justice, urban agriculture, labor, unpaid work, economic viability, exploitation, Boston, volunteers 


\section{Introduction}

While much has been written about the sustainability of alternative food initiatives (AFIs) with respect to environmental concerns, less attention has been paid to the factors that shape the economic sustainability and viability of alternative endeavors, especially with regard to the labor that is performed within them. This paper considers issues related to food work and economic viability by offering an analysis framed in terms of what constitutes alternative economic practices. Three AFIs in Boston are discussed, all of which are engaged in some form of urban agriculture: Higher Ground Farm, a commercial, for-profit enterprise; City Growers, a social enterprise that pursues both economic and social returns; and The Food Project, a nonprofit with a mission of "engaging young people in personal and social change through sustainable agriculture" (TFP, n.d.-a, para. 1). Based upon preliminary research, these three initiatives raise interesting and difficult questions regarding the economic conditions that enable them, especially with regard to the labor performed, since all three rely to some extent on significant amounts of unpaid work as well as other forms of transfer via cash or in-kind gifts. The prevalence of such unpaid or, in some cases, low-paid work raises questions about the economic viability of these initiatives and about whether alternatives such as these are able to provide "good jobs" along with "good food." 1 This is certainly an issue at play within the conventional food system, where economic logics and practices create conditions that make "bad jobs" prevalent (Food Chain Workers Alliance, 2012; Liu, 2012).

How, then, to make sense of unpaid work in alternative initiatives such as these? Is it indicative of economic exploitation or might it instead be part of what constitutes these initiatives as "alternative"? Might what Sbicca refers to as "nonmonetary valuations of work and labor within alternative food models" (2015, p. 676) be an

\footnotetext{
${ }^{1}$ What defines a "good job" will be addressed later. "Good food" refers to good quality, nutritious food. However, it is important to note that this relatively straightforward definition or "ordinary ethics of consumption" (Goodman, Maye, \& Holloway, 2010, p. 2) does not adequately interrogate the
}

indication of alternative economic logics that undergird the viability of AFIs? Further, might such alternative economic logics be constituted, in part, by economic practices that embody different metrics or standards with respect to economic viability, sustainability, and success? More specifically, might the presence of significant amounts of unpaid work and other forms of transfer be characteristic of alternative, noncapitalist logics and practices that are non-exploitative and that enable "progressive alternatives"? The answer to these questions depends in part on what is meant by "alternative" with regard to economic practices. However, while activists and practitioners have undertaken myriad initiatives that are cast as alternative to the dominant, "conventional," "industrial," "corporate" food system, there is little consensus among food scholars about what constitutes alternative economic practices and logics, much less alternative economic systems or networks (Alkon, 2014; Watts, Ilbery, \& Maye, 2005). As Watts et al. note in their literature review of alternative systems of food provision, "the conceptual basis of the 'alternative' food economy" is disputed" (2005, p. 22).

When addressing economic issues, some define alternatives by the extent to which they are "outside" the "conventional" or "industrial" food system (Watts et al., 2005), differ from a "corporate" model of food production (Lyson, 2007; Wilson, 2013) or are "oppositional to the industrial agri-food system" (McClintock, 2014, p. 8). Others assess alternatives with regard to whether or not they challenge neoliberal, free-market practices and subjectivities, rather than relying on market-based consumer choice, entrepreneurship, or "self-help" as avenues for social change (Alkon, 2014; Cadieux \& Slocum, 2015; McClintock, 2014).

"Alternative" has also been defined in terms of "food justice" and "social justice," with scholars, activists, and practitioners calling for initiatives that "eliminate disparities and inequities" in the current

myriad cultural, ethnic, social class, and ethical dimensions at play in defining what food comes to be regarded as "good." See Goodman et al. for a discussion of the "inescapably ethical/moral character of all food” (2012, p. 2). 
food system (Gottlieb \& Joshi, 2010, p. ix); and some of this activism and scholarship focuses especially on labor issues. Labor organizers and advocates such as the Coalition of Immokalee Workers, the Restaurant Opportunities Center, and the Food Chain Workers Alliance have brought growing attention to exploitative conditions facing many of those who work in the conventional food system. This activist engagement and "citizen science" has been complemented by academic scholarship that addresses food labor and economic inequality throughout the conventional food system (Alkon \& Agyeman, 2011; Barndt, 1999; Gottlieb \& Joshi, 2010; Lo, 2014), as well as at particular points along the food chain, such as on farms (Gray, 2014; Guthman, 2004; Holmes, 2013) and in restaurants (Sachs, Allen, Terman, Hayden, \& Hatcher, 2014). Guthman's 2004 study of organic farming in California served as a clarion call to many to address issues related to the exploitation and marginalization of food workers.

Concern for food justice in the conventional food system has also been mirrored by calls to incorporate "social justice" concerns within the alternative food movement (Alkon, 2014; Allen, 2010), and some of this scholarship addresses economic practices. This includes Allen's consideration of "material equity" and "the distribution of resources” (2010, p. 295), Sbicca's 2015 comparative case study analysis that looks at "fair food labor," and Cadieux et al.'s inclusion of "labor" that is not "alienating" and is "fairly compensated, protected, and valued" as one of the "four key points of intervention" for transformative food justice social change (Cadieux \& Slocum, 2015, pp. 2, 13-14). Yet, while there has been some reference to the importance of unpaid work in sustaining urban agricultural initiatives (Ballamingie \& Walker, 2013; McClintock, 2014; Myers \& Sbicca, 2015; Sbicca, 2015), overall relatively little attention has

\footnotetext{
2 In Boston, the living wage is estimated to be US $\$ 13.77 /$ hour (Glasmeier, 2016); this is almost 38 percent higher than the minimum wage of US $\$ 10 /$ hour in Massachusetts and 72 percent higher than the US\$8/hour minimum wage for agricultural workers in Massachusetts.

${ }^{3}$ Liu also includes "the opportunity to organize...into a collective bargaining unit without fear of employer retaliation" (2012, p. 2). While very important, this
}

been given to the significance of unpaid work and other forms of transfer in alternative food initiatives.

This discussion sits at the intersection of these concerns, as it considers what constitutes alternative economic practices with regard to the work performed in alternative food initiatives. In so doing, it focuses on labor practices within particular initiatives or "nodes" (Watts et al., 2005), with "alternative" understood in terms of non-exploitative labor practices. In regard to paid work, two standards of assessment are used when considering the labor practices in these three Boston AFIs. The first is whether the AFI is able to provide good jobs or decent work as well as good food-what Sbicca has called "fair food jobs" (2015)—and, if so, how; what enables this? The second is the extent to which the AFI is engaging in nonexploitative forms of food work. The first standard, that of whether the AFIs are able to provide good jobs, is essentially a question of whether these initiatives are able to pursue a "high road" to capitalism in which business success is predicated in part upon the long-term welfare of the people working in the business (Myers \& Sbicca, 2015; Reynolds, 2002). A good job is one that provides at least a living wage, ${ }^{2}$ along with benefits such as paid sick days and paid vacation, a safe work environment, adequate training, and relative job security. In a best-case scenario, it would also provide opportunities for upward mobility or "career pathways" (Liu, 2012, p. 1). ${ }^{3}$

In a society like the United States, where most people's ability to live a decent life depends upon having adequately paid work, the ability of any AFI to provide good jobs is very important. However, to the extent that the jobs created are waged work or commodified labor, with people working as employees of a private business owner, good jobs

concern is not much at play in the three AFIs discussed here. Further, as a reviewer noted, in some AFIs a good job may include more than monetary compensation to afford a decent standard of living. For instance, alternative endeavors may provide essential goods or services as a supplement to monetary wage payments, such as free or affordably priced housing, food, firewood, or health insurance. 
are not necessarily transformative in terms of creating economic alternatives to capitalism. Creation of decent waged work makes the work less exploitative by limiting the rate of exploitation. However, it does not eliminate labor exploitation itself, if exploitation is understood in Marxian terms of the performance of surplus labor as the basis for realizing a surplus value or profit. It is the second standard of assessment-whether the AFI engages in alternative economic practices by relying on non-exploitative food work - that addresses the extent to which the AFI is engaged in progressive, noncapitalist economic practices.

The discussion that follows also considers a third dimension of alternativeness: whether the initiative fosters progressive social change by creating "inclusive spaces for public participation and for social learning" about food systems (McClintock, 2014, pp. 6-7) that enable what Hassanein (2003) has called "food citizenship" and "food democracy." In considering this third dimension of alternative practices, the analysis follows Hassanein and Allen's lead insofar as they characterize the transformative potential of alternative endeavors to be that they open up spaces for "reflection, communication, and experimentation with alternative [more equitable] social structures" (Allen, 2010, p. 305), serving as "social laboratories" that create "spaces of resistance and creativity" (Hassanein, 2003, p. 79), a characterization of alternative practices that is similar to what Gibson-Graham has called a "politics of economic possibility" (2006, p. xix). These concerns dovetail with those who see alternatives at play in "civic agriculture" (DeLind, 2003; Lyson, 2007) and in community networks that engage in a "reflexive local politics" oriented toward creating sustainable, democratic, and equitable community food systems (Dupuis \& Goodman, 2005). They also dovetail with a broader field of scholarship and activism interested in fostering "community economies" (Biewener, 2001; Community Economies Collective, 2001; Gibson-Graham, 2006, 2008), a "solidarity economy" (Dacheux \& Goujon, 2011; Loh \& Shear, 2015), or a "social economy” (Amin, 2009; Biewener, 2006; Connelly, Markey, \& Roseland, 2011) that build "interplace solidarity" and progressive, redistributive forms of "interdependence" (Gibson-Graham, 2006, pp. 622-623).

These three initiatives-Higher Ground Farm, City Growers, and The Food Project-are examined because they all have been characterized as "alternative" within Boston's activist "good food" community. They all are involved in urban agriculture and, therefore, share some similar challenges and opportunities as a food-system endeavor. They also represent a spectrum with regard to their ability to provide decent work as well as with regard to the extent of their alternative economic practices. While further research is needed to fully explore the alternative economic practices and logics at play in each of these initiatives, several conclusions can be made based on this preliminary research. First, when consideration is given to economic practices, some initiatives that have been cast as alternative, such as Higher Ground Farm, are not necessarily able to provide good jobs, nor are they engaging in progressive, alternative economic practices. Second, initiatives that combine a concern with providing good jobs, non-exploitative labor practices, and a reflexive food politics oriented toward building equitable and sustainable community food systems - as in the case of City Growers and The Food Project-provide a better alternative economic model. Finally, since all three AFIs rely on significant amounts of unpaid work, it is important to consider what delineates exploitative from non-exploitative forms of unpaid work. The last section of this article therefore reflects on the nature and implications of unpaid work in these three AFIs by addressing three questions: How is unpaid work understood and fostered in the AFIs; what are the conditions that enable it; and is it indicative of alternative, noncapitalist economic logics and practices?

\section{Research Methods}

The discussion that follows is based on preliminary research that was carried out between June 2014 and August 2015. The analysis relies primarily on secondary sources, including print and online articles, websites, and printed material for all three AFIs, as well as IRS 990 forms and annual reports for The Food Project. It also incorporates insights from field notes taken after attending five 
Massachusetts Food Policy Council meetings, participating in The Food Project's three-day summer institute in August 2015, volunteering at Higher Ground Farm (HGF), speaking with interns at HGF's booth at Boston's 2014 Local Food festival, participating in a Regional Forum held as a part of the process for developing the recent Massachusetts Local Food Action Plan, and participating in two public meetings held as a part of Boston's urban agriculture visioning process. In the circumstances in which I was in direct conversation with individuals, I always disclosed that I am an academic engaged in research related to job quality and economic viability in food-system initiatives. I also asked for permission to write about and publish information gained from such conversations.

\section{Higher Ground Farm: A For-profit Enterprise}

I begin with an example of an endeavor that has gotten a lot of positive press within Boston's good food community, but which I find to be problematic with regard to both its economic viability and the extent to which it offers a progressive alternative with respect to economic practices.

Higher Ground Farm (HGF) is Boston's largest commercial urban agricultural enterprise, comprising $14,000 \mathrm{ft}^{2}\left(1,300 \mathrm{~m}^{2}\right)$ of space on the roof of the Boston Design Center (BDC), New England's "preeminent destination for luxury interior furnishings," located in the Seaport District (BDC, n.d., para. 1). Started by Courtney Hennessy and John Stoddard, graduates of the University of Vermont environmental studies program, the farm had its first growing season in 2013. From its inception, Hennessy and Stoddard were motivated to "produce and market the freshest of foods, while simultaneously providing environmental benefits to the community by increasing green, permeable space in the city, and reducing carbon emissions" (Annear, 2012, para. 5). After the third growing season, HGF remains true to its goal of providing healthy, fresh produce to local restaurants and residents, as illustrated by its mission statement: "Our mission is to be a viable green business that will provide fresh, healthy, city-grown produce to residents and local restaurants, while providing a space that reconnects urban-dwellers with productive green space" (HGF, n.d.).

As a private, for-profit microenterprise, Hennessy and Stoddard's commercial model is based on producing and selling greens, vegetables, and flowers to local restaurants, as well as to the local community through a farm stand in the lobby of the Design Center. Based on Hennessy's restaurant connections built through years of working in farm-to-table restaurants as a server, bartender, bar manager, and general manager, HGF has developed an impressive clientele of high-end restaurants and several grocery stores. "I was in in the restaurant business for eight years,' Hennessey [recounted], 'and I've worked for a lot of really big name chefs. We thought that, with the relationships we have, the experience we have, this would be a good business to start. So we just went for it" (Wakefield, 2014, para. 8). With restaurant deliveries made via bicycles, HGF has positioned itself as being a hyperlocal provider of some of the freshest produce in Boston restaurants. "We harvested and delivered it that morning, it was in the chef's hand by 4 p.m., and my friend is eating it at midnight. It's crazy!"” (Landry, 2013, para. 13).

The initial capital investment to install the open-air rooftop farm was financed by a Kickstarter campaign that raised over US $\$ 23,000$ (Landry, 2013, para. 9), along with a sold-out benefit concert that raised another US $\$ 10,000$ (Holt, 2013, para. 6). However, this initial financing fell short of the US $\$ 300,000$ that Hennessy and Stoddard had estimated would be needed to fully develop the entire BDC roof area (Boyer, 2013, para. 2). In the 2015 growing season, HGF continued to farm on just over a quarter of BDC's $55,000 \mathrm{ft}^{2}\left(5,110 \mathrm{~m}^{2}\right)$ roof, using milk crates as soil containers (Field notes). Eventually, Hennessy and Stoddard hope to expand the farm to encompass $40,000 \mathrm{ft}^{2}\left(3,716 \mathrm{~m}^{2}\right)$ of produce planted in soil on the rooftop itself, with another " $15,000 \mathrm{ft}^{2}(1,394$ $\mathrm{m}^{2}$ ) of harvest stations and support equipment" (Kahn, 2013, para. 3).

For its first three growing seasons, the farm ran purely on volunteer labor. This was not a surprise to either Hennessy or Stoddard since, from the start, they had anticipated a low return, with "their big hope [being] for the business to support 
them fully within three to five years" (Landry, 2013, para. 11). In the meantime, both of them are working paid jobs (Hennessy in restaurants and Stoddard as the New England regional project coordinator for the nonprofit organization Health Care Without Harm). Additionally, HGF relies on one to two unpaid interns per growing season and on volunteers, whose help is especially needed on the volunteer days at the beginning and end of each growing season to set up and then disassemble the irrigation and milk crate infrastructure and for the post-harvest clean-up.

HGF is an important pioneering effort to create the first viable commercial roof-top farm in the greater Boston area. It promises to offer significant environmental benefits insofar as it reduces storm water runoff loads, provides energy-saving insulation for the building, adds carbon-breathing plants to the city's landscape, may contribute to the neighborhood's "heat island" management, and reduces the energy needed to deliver fresh, nutritious produce to local restaurants. However, it has not been able to provide good jobs in addition to its good food. For its first three growing seasons, its viability has relied upon a significant amount of unpaid work from the two "founding farmers," unpaid interns, and volunteers, This unpaid work has essentially subsidized the meals produced at high-end restaurants and the produce sold to highend grocery stores and to the relatively well-heeled people who buy food at the HGF farm stand at the Design Center. Indeed, from an economic perspective the alternative nature of HGF's economic practices is limited. First, there is the important question concerning the extent to which HGF's commercial success will continue to depend upon the self-exploitation of the farmer-operators themselves whereby, as Guthman has characterized selfexploitation, the farmers do not earn "revenues equal to the cost of their own labor" (2004, p. 83). This is certainly a concern that confronts many small farming enterprises (Galt, 2013; Hinrichs, 2000; Jarosz, 2007). Secondly, should HGF ever be in a position to employ people for a wage, there is the question of whether it will be able to provide good jobs and, thereby, be an example of highroad capitalism. Given the difficulties of providing decently paid farm jobs in any farming operation,
HGF will likely face considerable challenges achieving this. At best it will become a commercially viable (i.e., profitable) small business, owned and operated by two relatively privileged people (both are college-educated, white, and middleclass), with its alternative character relying on its being small, local, and able to produce some amount of good food in a sustainable and environmentally responsible manner.

\section{City Growers: A Social Enterprise}

City Growers (CG) is another commercial, forprofit enterprise, but one that explicitly embraces a double bottom line by pursuing both economic and social returns. Cofounded in 2010 by Glynn Lloyd and Margaret Connors, this social enterprise had its first season of farming in 2012, one year before HGF. Lloyd is a schoolteacher turned entrepreneur. In 1994, he was one of the three founders of City Fresh Foods, a successful community-based catering business that offers "culturally appropriate food" to Latino and African American senior citizens. Over 15 years later, he partnered with Margaret Connors, a former public-school wellness coordinator, to establish City Growers.

CG's mission is to "transform vacant lots in Boston into intensive urban farms that are economically and environmentally sustainable" (CG, n.d.-a, para. 1). As Lloyd describes it, he "had an epiphany" some years ago; "I was standing in the kitchen at City Fresh and realized that we were buying all this lettuce from California and paying a pretty good dollar for it,' he recalls. 'Then I was driving up Harold Street [in Roxbury] and I just noticed vacant lot, vacant lot, vacant lot, vacant lot. I said, "We are going to get land and start growing food" (Harris \& Lyon, 2013, para. 1).

CG began farming in 2012 with about half an acre (.2 hectare) of farmable land. By the 2015 growing season, it doubled that number to one acre (.4 ha), spread over four different plots in two of the poorest parts of Boston, Roxbury and Dorchester; neighborhoods that have also experienced the greatest amount of abandonment and neglect. The hope is to establish a "checkerboard" of intensively farmed, quarter-acre (.1 ha), microfarms that are "linked into a single entity (City Growers) with coordinated market operations and pooled 
resources" (Harris \& Lyon, 2013, para. 13).

As Connors has characterized it, CG's vision is one of "sustainability," both environmentally and economically. CG believes that urban farms that are reliant on grants and foundation support are vulnerable, not sustainable. "Building a new food system dependent on grant funding puts that food system at risk, particularly in turbulent economic times and always for those most in need" (Connors, 2012). CG is searching for a

new model...We're not just growing food in poor neighborhoods.... Our intention is to establish a resilient food system as an alternative to our current, broken food system. We are looking to business models based on sales of products and services to survive even in times of economic downturn. (Connors, 2012)

In establishing commercial farms on formerly vacant land in underserved communities, CG has identified three major goals: "1. Creating employment for community members at livable wages, 2 . Addressing food security issues by increasing local agricultural production capacity, and 3. Increasing local access to affordable, nutrient-rich foods" (CG, n.d.-a, para. 2).

Similarly to Higher Ground Farm, CG's commercial strategy rests in part upon advertising its produce as hyperlocal. As its poster proclaims, CG provides produce that is "City Farmed, City Sold." Like HGF, some of its produce (mostly greens) is marketed to high-end restaurants and grocery stores located in wealthy communities. However, CG has a more diverse clientele than HGF, as it also includes more moderately priced restaurants and grocery stores in moderate-income communities. CG's clientele also includes social enterprise caterers such as City Fresh Foods and Haley House Bakery Café, a bakery and catering business in Roxbury that is run by formerly homeless men.

While CG wrestles with determining the best organizational structure and scope for realizing a "new UA [urban agriculture] model," currently it has a "cooperative model" in which City Growers is the "brand," operating as a commercial wholesale seller for individual farmer-members. During the 2012 growing season, CG grew on $20,000 \mathrm{ft}^{2}\left(1,858 \mathrm{~m}^{2}\right)$ (about half an acre [.2 ha]) and generated US\$32,600 in sales. For Connors, "that really proved our model" (Harris \& Lyon, 2013, para. 6). The company employed one parttime and two full-time growers; it also got assistance from about 100 volunteers (Harris \& Lyon, 2013, para. 6). The goal is for one part-time and two full-time farmers to sell at least US $\$ 40,000$ on one-half acre $(.2 \mathrm{ha})$, allowing them to earn US $\$ 15,000$ to US $\$ 18,000$ in a 22 to 25 week growing season (Connors, 2012). As Table 1 shows, with Boston's living wage estimated to be US $\$ 13.77 /$ hour (Glasmeier, 2016), this would provide income that exceeds the living wage for five to six months a year, assuming a forty-hour work week.

City Growers estimates that at six intensely farmed acres (2.43 ha) it will reach "the breakeven point," with earnings from three to four acres (1.21 to $1.62 \mathrm{ha}$ ) used to cover the shared functions of management, sales, transportation, bookkeeping, and marketing, with earnings from the other two to three acres (.81 to $1.21 \mathrm{ha}$ ) providing income for the individual farmers. The longer-term hope is to acquire 10 to 15 acres (4 to 6 ha), which would allow farmers to grow on multiple intensive minifarms, potentially reaching US $\$ 1,000,000$ in sales (assuming earnings of US $\$ 4,000$ per week per acre) (Rajewski, 2011, para. 27).

Table 1. Estimated Weekly and Hourly Earnings of City Grower Farmers (all values in US\$)

\begin{tabular}{lccccc}
\hline $\begin{array}{l}\text { Range of } \\
\text { Earnings }\end{array}$ & Total Revenue & $\begin{array}{c}\text { Length of } \\
\text { Growing Season }\end{array}$ & $\begin{array}{c}\text { Revenue } \\
\text { per Week }\end{array}$ & $\begin{array}{c}\text { Earnings per 40- } \\
\text { Hour Work Week }\end{array}$ & $\begin{array}{c}\text { Percentage of } \\
\text { US } \$ 13.77 / \text { hour } \\
\text { Living Wage }\end{array}$ \\
\hline Low End & $\$ 15,000$ & 25 weeks & $\$ 600.00$ & $\$ 15 /$ hour & $108.9 \%$ \\
\hline High End & $\$ 18,000$ & 22 weeks & $\$ 818.18$ & $\$ 20.45 /$ hour & $148.5 \%$ \\
\hline
\end{tabular}

Source: Data on total revenue and length of growing season from Connors, 2012. 
In addition to selling produce to restaurants and food retailers, CG's economic viability therefore depends on the acquisition of farmable land as well as the labor of people with farming skills. Fortunately, thus far CG has been able gain access to some land at a relatively low cost by leasing a quarter acre $(.1 \mathrm{ha})$ "for next to nothing" from the Sportsmen's Tennis Club in Dorchester (Rajewski, 2011, para. 7) and leasing another two parcels totaling a quarter acre from the city of Boston for US $\$ 100$ per year (Hansman, 2014, para. 8$).{ }^{4}$ Yet even given the possibility of acquiring such lowcost city-owned parcels, which effectively entails subsidized access to land (Galt, 2013), CG faces significant upfront capital investments for land remediation and the building of basic infrastructure on each parcel (e.g., water hook-ups, composting, landscaping). While the land has been virtually free, about US $\$ 25,000$ has been spent just to prepare the soil for cultivation on each quarter acre (.1 ha) (CLF, 2012, p. 32). CG has sought out myriad sources of funding for these initial capital expenditures, including grants from foundations, government grants, "angel" investors, and a Kickstarter campaign that raised close to US $\$ 30,000$ (CG, 2013, para. 1). At the same time, CG has partnered with two nonprofit organizations, the Urban Farming Institute (UFI) and New Entry Sustainable Farming, ${ }^{5}$ to provide farmer training. CG and UFI reach out to residents

\footnotetext{
${ }^{4}$ As a part of former Mayor Menino's Initiative for Food Policy, in 2013 the Boston Redevelopment Authority (BRA) undertook an inventory of city-owned vacant land to determine what might be suitable for agriculture. Boston also rezoned land in December 2013 to allow for commercial urban agriculture throughout the city. Known as Article 89, this was "the most comprehensive piece of legislation of its kind” (Hansman, 2014, para. 6). As a part of the city's multipronged effort to encourage urban farming, the BRA took requests for proposals from potential farmers, leasing parcels for US $\$ 100$ each, "with a caveat that the land be specifically used for farming for 50 years" (Hansman, 2014, para. 8). CG was one of the first two organizations to farm on the city-owned land, along with Victory Programs ReVision Urban Farm, which grows produce for homeless women. CG estimates that there may be over 800 acres (324 ha) suitable for urban farming in Boston (CLF, 2012, p. 12).

5 The Urban Farming Institute was established as a nonprofit in 2012 "to support the development of urban farming in Boston....Besides serving as an advocate for urban farms in
}

living in the communities in which they farm, the three most underserved communities in Boston. CG has also had the help of one to three farm apprentices and approximately 400 volunteers each year (Shemkus, 2014, para. 8).

Thus CG compares favorably with HGF in terms of being able to provide some amount of decent paid work, as neighborhood farmers appear to be able to earn an income that is somewhat higher than Boston's living wage. ${ }^{6}$ This realizes one of CG's three major goals, that of creating employment for community members at livable wages. Yet this work is not full-time, nor does it provide fringe benefits. CG is keenly aware of these limitations and is working assiduously to fashion creative ways to enable CG farmers to earn a decent, stable, year-round income. For instance, two of CG's first farmers, Bobby Walker and Nataka Crayton, are now also working as "farmer trainers" for the Urban Farming Institute during Boston's long nongrowing season.

As a small, for-profit enterprise, CG is also trying to establish an economic model built on economic practices that are more alternative than those of HGF. As noted above, CG functions as a social enterprise, explicitly combining defined social mission goals with the pursuit of commercial viability. This social mission includes training local community residents to be urban farmers, turning abandoned vacant land in underserved

policy discussions, UFI's principal tasks are to incubate farms and incubate farmers" (Harris \& Lyon, 2013, para. 19). Glynn Lloyd of City Growers was active in establishing UFI and serves on the Board. New Entry Sustainable Farming is affiliated with Tufts University. It works "with new farmers to build strong business, expertise in the field, and a resilient food system" (New Entry Sustainable Farming, n.d., para. 1).

${ }^{6} \mathrm{I}$ do not have enough information about HGF's and CG's incomes and expenses to explain fully why CG farmers have been able to earn income while HGF farmers have not. I suspect it has to do with initial capital expenditures needed to start the respective farming endeavors, with HGF's rooftop enterprise requiring a more substantial initial capital investment. It may also be that HGF faces higher operating costs, such as higher expenses for water and compost and for leasing BDC's rooftop. Finally, it may also be that HGF farmers are saving any earnings to fund future development and expansion of the rooftop farm. I hope that future research will answer these questions. 
communities into fertile and fruitful agricultural enterprises, and providing fresh, nutrient-rich produce to a range of nonprofits that serve the local community. It is building, thereby, social, financial, and physical assets in the communities in which it farms, communities that are much less well-off than those who frequent HGF's farm stand at the Boston Design Center. Further, CG is structured in a more democratic manner than HGF, as it is currently functioning as a cooperative, with shared decision making regarding resource allocation and use of revenues. It is, thereby, "diversifying forms of [non-exploitative] food labor and work relations" (Sbicca, 2015, p. 676). CG is also developing creative ways of combining nonmarket streams of support to subsidize up-front investments in farmer training by partnering with Tufts University's Sustainable Farmer's Program and the Urban Farming Institute, as well as hoping to have UFI take on the costs of soil remediation, policy research, and community education (Connors, 2012). While CG faces considerable challenges to fully realizing its social and economic vision, it has, thus far, created significant space for envisioning and enacting an urban agriculture model that is "predicated on fair and democratic labor practices" (Sbicca, 2015, p. 685), as well as one that is indicative of a reflexive local politics oriented toward creating a sustainable, democratic, and equitable food system within the communities in which they farm.

\section{The Food Project: A Nonprofit}

Founded in 1991, The Food Project (TFP) has been farming for 25 years. It is, therefore, by far the most established of the three initiatives. TFP uses land stewardship and sustainable agriculture as a youth leadership development tool. With four urban growing sites (two in Boston and two in Lynn) and five suburban sites (in Lincoln, Wenham, and Beverly), TFP harvests over 270,000

\footnotetext{
${ }^{7}$ Beginning in 2008, TFP was the first to offer SNAP benefits (Bounty Bucks) at farmers markets in Massachusetts.

${ }^{8}$ In 2013 , the state minimum wage was US\$8/hour, putting the Seed Crew's stipend at 10 percent less than the minimum wage, the Dirt Crew's at 3 percent more, and the Root Crew's at just over 15 percent more. Given that a number of UA
}

pounds (122,470 kilograms) of produce annually on its 40 acres (16 ha) of farmland (TFP, 2014, p. $3)$.

Twenty to 25 percent of TFP's produce is donated to 12 hunger relief organizations. The rest is sold at four farmers markets in low-income neighborhoods in Boston and Lynn and through four community supported agriculture (CSA) programs, including a subsidized CSA. ${ }^{7}$ In 2014, TFP generated US $\$ 412,056$ in revenue from the sale of produce (TFP, 2014, p. 11).

Each year, TFP's staff work with some 115 to 120 teenagers and thousands of volunteers. For instance, in 2012, 2,715 farm volunteers contributed 7,670 hours through TFP's volunteer program, Serve and Grow (TFP, 2013, p. 5). Teenagers are first employed to work in the "Seed Crew" for six and a half weeks in the summer, receiving a stipend of US $\$ 1,845$ (in 2013), which TFP considers equivalent to a pay rate of US $\$ 7.25 /$ hour. Seed Crew teens who are interested in continuing their work with TFP are then able to join the "Dirt Crew," which hires 20 to 30 youth to continue throughout the academic year. In 2013, the Dirt Crew stipend was US $\$ 1,818$ (equivalent to US $\$ 8.25$ /hour). Finally, teens can continue on to a capstone internship-like experience by working in the "Root Crew." In 2013, 25 youth worked as Root Crew members, earning a stipend of US $\$ 2,076$ (equivalent to US $\$ 9.25 /$ hour) (TFP, 2013, p. 7; CG, n.d.-b, para. 3). ${ }^{8}$

In addition to learning sustainable agriculture practices, youth are introduced to issues related to local food systems, food justice, and food access. As the Director of Programming and Institutional Learning Cindy Davenport, noted, "We are about much more than inclusion. We educate for systems change, addressing issues of inclusion, diversity, oppression, and anti-oppression" (Field notes, TFP Summer Institute, August 2015). For Dirt Crew members, engagement and activism around

initiatives incorporate youth employment and training as part of their mission, an area for further research would be that of considering the extent to which TFP provides relatively good jobs for youth, as well as opportunities for training, advancement, and even permanent forms of employment as in the case of Jess Liborio, discussed later. 
community food-access issues are furthered during the school year through the design and execution of a long-term, self-directed project that addresses food access issues, such as collaborating with the Boston Public Health Commission to research why corner stores in urban areas rarely stock fresh produce, or teaming up with a local high school to design and build raised-bed gardens. Leadership development is furthered for Root Crew members by having them staff the farmers markets, manage farm share distribution and drop-off points, serve as peer leaders to support the youth in the Seed Crew, and build raised beds for low-income families (Field notes, TFP Summer Institute, August 2015).

One of TFP's considerable achievements is its ability to build bridges and foster relationships among youth across significant racial, ethnic, and class divides as they bring together teens from Boston's urban and suburban areas. TFP is also adept at building bridges with other community groups in Boston's lowest income neighborhoods. In 2010, they partnered with the Dudley Street Neighborhood Initiative9 to operate the $10,000 \mathrm{ft}^{2}$ $\left(929 \mathrm{~m}^{2}\right)$ Dudley Greenhouse in Roxbury. Half the greenhouse is designated for enterprise, in which TFP grows produce to sell at a market rate to local restaurants. These beds produce greens in the fall and winter and tomatoes in the spring and early summer. The profits from these sales provide much of the revenue that supports the other half of the greenhouse, called the Community Bay, which serves as a community space. This part of the greenhouse features 27 raised beds in which eight community groups (schools, health centers, and refugee groups) and local gardeners grow produce for themselves and their neighbors. The Dudley Greenhouse serves as a year-round learning center; as Anguelovski (2014) shows, it also serves as a place of refuge for new immigrants and as a

\footnotetext{
9 The Dudley Street Neighborhood Initiative was created in the mid-1980s by community organizing and activism to "reclaim a neighborhood that had been ravaged by disinvestment, arson fires and dumping. DSNI's mission is to empower Dudley residents to organize, plan for, create, and control a vibrant, diverse and high quality neighborhood" (DSNI, n.d.-a, para. 1) . In 1988, the city of Boston granted DSNI eminent domain over 1,300 parcels of abandoned land
}

place for community building.

In 2011, TFP expanded upon its community partnerships by initiating the "Dudley Food Planning Process" that involved both DSNI and another local nonprofit, Alternatives for Community and Environment (ACE), well-known for its years of effective organizing around environmental justice issues. By 2014, the Dudley Food Plan was oriented toward creating a "strong, resilient food system that serves the neighborhoods" (TFP, 2014. p. 8). TFP's vision of a community food system is a fairly radical, rightsbased perspective that goes beyond "mere... food access":

We believe that every person has a right to real food. This right extends beyond the consumer's purchasing power: every person has the right to access the space, knowledge, and resources for growing the food they eat and to access fresh and nutritious food grown by others. It is only when people engage with each other around multiple aspects of the food system, from seed to plate, that a stronger community food system is built. (TFP, n.d., para. 3)

TFP calls its "holistic approach" to community programs "the Real Food Hub model":

A Real Food Hub is a partnership between The Food Project and local community institutions to support the health of children and families through better access to healthy food: growing it, purchasing it, preparing it, and sharing it with their neighbors. Real Food Hubs link TFP's expertise in sustainable agriculture, youth development, and community food systems with the expertise of our partners in education, family support

(over 30 acres [12 ha]) in the Dudley Triangle area of Roxbury. A community land trust was formed, Dudley Neighbors, Inc., and, since then, the land "has been transformed into 225 new affordable homes, a 10,000 square foot [929 $\left.\mathrm{m}^{2}\right]$ community greenhouse, an urban farm, a playground, gardens, and other amenities of a thriving urban village," including a town common and a charter school (DSNI, n.d.-b, para.3). 
services, community organizing, and community development. Combined, our programs can achieve more than mere food access - they give families the skills, tools, and resources to define healthy food options and practices that build physical, social, and cultural well-being. (TFP, n.d.-b, para. 4)

How does TFP sustain itself economically? Since 2004, TFP revenue has varied between a low of US\$2.75 million in FY2004, to a high of US\$3.65 million in FY2010 (IRS, 2004 to 2013). For FY2014, revenues totaled US\$2.66 million, with US $\$ 412,056$ earned from food sales at farmers markets and via CSAs, accounting for only 15.5 percent of total revenue (TFP, 2014, p. 11). ${ }^{10}$ As Table 2 shows, in 2014 almost 80 percent of TFP revenues were from donations (five to six percent less than the average over the previous 10 years). The remainder came from investment income $(3.3 \%)$, programs and training materials $(1.3 \%)$, and raffles $(0.4 \%)$.

Of the over US\$2.1 million in donations in the 2014 fiscal year, 68 percent were from "individuals and family foundations," 17 percent were from private foundations, and nine percent were from corporations (see Table 3). This breakdown among the various donation categories is more or less consistent with TFP's prior 10 years.

Notably, year after year revenues from food sales do not cover even half the expenses related to food production. In FY2014, for instance, revenues from food sales (US\$412,056) only covered about 43 percent of

10 This compares favorably with the prior 10 years, as food sales fluctuated between a low of $9.9 \%$ of total revenue in
Table 2. The Food Project's Total Revenue (in US\$), FY2014 (July 1, 2013-June 30, 2014)

\begin{tabular}{lrc}
\hline & Revenue (US\$) & $\begin{array}{c}\% \text { of Total } \\
\text { Revenue }\end{array}$ \\
\hline Donations & $\$ 2,118,250$ & $79.5 \%$ \\
\hline Food Sales & $\$ 412,056$ & $15.5 \%$ \\
\hline Investments & $\$ 89,001$ & $3.3 \%$ \\
\hline Programs \& Training Materials & $\$ 34,767$ & $1.3 \%$ \\
\hline Raffles & $\$ 10,705$ & $0.4 \%$ \\
\hline Total Revenue & $\$ 2,664,679$ & $100.0 \%$
\end{tabular}

Source: TFP, 2014, p. 11.

Table 3. The Food Project's Monetary Donations (in US\$) by Source, FY 2014 (July 1, 2013-June 30, 2014)

\begin{tabular}{lcc}
\hline & Revenue (US\$) & $\begin{array}{c}\text { \% of Total } \\
\text { Revenue }\end{array}$ \\
\hline Individuals \& Family Foundations & $\$ 1,440,341$ & $68.0 \%$ \\
\hline Private Foundations & $\$ 360,086$ & $17.0 \%$ \\
\hline Corporations & $\$ 190,634$ & $9.0 \%$ \\
\hline Other Organizations & $\$ 84,726$ & $4.0 \%$ \\
\hline Government Grants & $\$ 42,363$ & $2.0 \%$ \\
\hline Total Monetary Donations & $\$ 2,118,150$ & $100.0 \%$
\end{tabular}

Source: TFP, 2014, p. 11.

Table 4. The Food Project's Expenses by Category (in US\$), FY2014 (July 1, 2013-June 30, 2014)

\begin{tabular}{lcc}
\hline & Revenue (US\$) & $\begin{array}{c}\% \text { of Total } \\
\text { Revenue }\end{array}$ \\
\hline Youth Development Programs & $\$ 1,242,541$ & $42.7 \%$ \\
\hline $\begin{array}{l}\text { Urban Farming \& Community } \\
\text { Agriculture }\end{array}$ & $\$ 544,525$ & $18.7 \%$ \\
\hline Suburban Farming & $\$ 406,087$ & $14.0 \%$ \\
\hline Volunteer \& Outreach Programs & $\$ 393,636$ & $13.5 \%$ \\
\hline Food Access & $\$ 322,965$ & $11.1 \%$ \\
\hline Total Expenses & $\$ 2,909,754$ & $100.0 \%$ \\
\hline
\end{tabular}

Source: TFP, 2014, p. 11.

food production expenses. As shown in Table 4, food production activity expenses for "Urban Farming \& Community Agriculture" and "Suburban Farming" came to US\$950,612 in

FY2005 and a high of 16.2\% in FY2013 (IRS, 2004 to 2013). 
FY2014, about one-third of TFP's overall expenses.

While monetary donations have been crucial for maintaining TFP's economic viability, gifts in kind have also been important. These nonmonetary transfers include land leased at virtually no cost from local towns and The Trustees of Reservations, ${ }^{11}$ many hours of volunteer labor, and myriad other "services, materials, food, and beverages" from some 45 restaurants, food retailers and caterers, landscape design companies, garden supply stores, and printing companies (TFP, 2013, p. 15).

TFP therefore has been able to successfully combine substantial commercial agricultural activity with mission-driven, nonprofit work. Of the three AFIs surveyed, only TFP has been able to consistently provide decent paid work for its staff. The paid staff includes the executive director and a leadership team of five who oversee 21 full-time staff, two part-time staff, nine seasonal employees, five fellows sponsored by various foundations, and four FoodCorps Service members (TFP, 2013, p. $3)$. In 2013, the executive director received compensation of US $\$ 118,073$, having increased steadily from US\$70,000 in 2004 (IRS, 2004 to 2013). While other compensation data is not publically available, staff that I spoke with at the 2015 Summer Institute indicated that their jobs afforded them a decent standard of living. ${ }^{12}$ TFP staff also receive health benefits and paid vacation (beginning with two weeks of paid vacation a year, and rising over time to four weeks). They do not, however, receive contributions to a retirement account. In addition to decent wages and benefits, TFP also cultivates opportunities for upward mobility. There are many examples of employees who, over time, have moved up in the organization, including the

\footnotetext{
11 As the oldest land trust in the United States, The Trustees of Reservations is a member-supported, nonprofit land conservation and historic preservation organization. It owns over 100 properties in Massachusetts, on 25,000 acres (10,117 ha) of land (The Trustees of Reservations, n.d., para. 2).

12 As in most nonprofits, TFP salaries are set by the executive director such that, in this regard, TFP is not unusual or "alternative." While the organization reportedly operates on a "consensus model," this is clearly not the case with respect to compensation. Up until about four years ago, the budget was an open document, including information about salaries (Field
}

current executive director, James ("J") Harrison, who began in 2005 as the farm manager for one of TFP's North Shore farms. By 2008, he was promoted to be the director of agriculture for the entire organization. He subsequently worked as the regional director in the North Shore until his appointment as acting executive director in October 2014, and then his appointment as executive director in January 2015. Former members of the youth crews have also moved on to become full-time paid members of TFP's adult staff. For instance, Jess Liborio, TFP's Greater Boston Programs \& Community Outreach Manager, first worked at TFP in 1995 as a teenager on the Dirt Crew. Ten years later, she returned to work as a farm manager for one of TFP's urban farms in Lynn (Field notes, TFP Summer Institute, August 2015).

TFP's economic practices are noncapitalist, as are the logics and metrics it uses to allocate resources and to assess its success. As such, it is an important example of an AFI that engages in a range of alternative economic practices that enable its viability. It is notable that the decent waged work that TFP provides is not afforded solely by revenues from its farming operations. Year after year, TFP's farming revenues do not even cover the costs of its farming operations. Rather, monetary donations from individuals, businesses, and foundations finance the large majority of TFP expenses. These donations are forthcoming because TFP is a mission-driven organization whose bottom line is not determined by the commercial profitability of its food production operations. ${ }^{13}$ Instead, TFP's economic viability and sustainability rests squarely upon its ongoing ability to convince donors (of both money and time) that

notes, TFP Summer Institute, August 2015).

13 TFP's youth leadership development mission constrains the efficiency and therefore the returns from its farming operations in several respects. For instance, according to the assistant farmer on TFP's 30-acre (12 ha) Lincoln farm, TFP does not use as much machinery as a conventional farm would because of concerns about operating farm machinery with so many teenagers working in the fields. On its urban farm sites, safety concerns preclude youth from using sharp tools, such as knives, for harvesting produce (Field notes, TFP Summer Institute, August 2015). 
it is engaging in practices and achieving outcomes that are worthy of their ongoing support. These include community-building activities that foster thoughtful engagement across significant racial and class differences, especially through youth engagement and leadership development. Community building also occurs via community gardening, community education, and through TFP's work with other social change organizations to envision, plan for, and slowly build equitable, sustainable, and democratic community food systems in the neighborhoods in which TFP works. In so doing, TFP fosters critical consciousness and a reflexive local politics, practicing what Hassanein (2003) has called "food democracy" and "food citizenship."

\section{Paid Work, Unpaid Work, and Alternative Economic Practices}

The three AFIs surveyed here represent a spectrum with respect to their ability to provide good jobs along with good food, and with respect to their alternative economic practices and their engagement in a reflexive local politics. TFP sits at one end of the spectrum, providing the best jobs of the three, as well as the most alternative set of economic practices and most extensive engagement with a reflexive politics. CG sits in the middle, and HGF is situated at the other end, unable thus far to provide any paid work at all, much less good jobs, following relatively conventional small business practices, and not actively engaged in a reflexive politics. The difficulties that CG and HGF face in trying to provide living-wage jobs speak to the significant challenges to being commercially viable that any urban agriculture initiative faces. This is perhaps especially true for those endeavors, like CG and HGF, which are in their initial years. Trying to earn a decent living from farming is, we know, "a hard row to hoe." In contrast, one of the reasons that TFP has been successful is that it does not rely on sales of food produce to maintain its economic viability. Instead, it relies on a considerable amount of transfers, including donations in the form of volunteer labor. Indeed, as noted at the outset, unpaid work has been a crucial factor in sustaining all three of the urban agriculture initiatives discussed here.

While agro-food scholars and practitioners have had some discussion of the pros and cons of AFIs relying more on grant and donor funding than on commercial revenue streams, there has been little intensive study into the prevalence of unpaid labor within AFIs. In what follows, therefore, consideration is given to the nature and implications of the unpaid work that is performed in these AFIs by addressing three questions: How is unpaid work understood and fostered by these three AFIs; what are the conditions that enable it; and is it indicative of alternative, noncapitalist economic logics and practices?

Unpaid food work is not commodified work since it involves labor that is performed without receiving a wage. As such, it is noncapitalist and, therefore, an alternative to capitalist labor relations. Yet, in itself, uncommodified work or unpaid work is not inherently less exploitative or more just than capitalist wage-labor. We need only consider the long histories of slavery, feudalism, and sharecropping to bring this point home. Further, a considerable amount of food production and processing has always depended upon unpaid labor, often performed by women. This is evidenced by the substantial amount of subsistence food production that takes place throughout the world, small family farmers' reliance on the unpaid work of their wives and children (Jarosz, 2007; Ramey, 2014), and all the work that takes place in households to acquire and produce meals. All the unpaid labor that takes place throughout the food system is likely an important factor in explaining why so many of the paid food-system jobs are so poorly paid. It is important, therefore, to consider what might delineate non-exploitative forms of unpaid work from exploitative ones, so that we might understand what conditions would enable unpaid work to be a facet of progressive alternatives.

At least three different discourses or logics are at play with regard to the unpaid work that sustains these three AFIs. First, in the case of Higher Ground Farm, there is a discourse of unpaid work as an investment. The enormous amount of unpaid time that the two founding farmers have spent over the past three growing seasons is cast in terms of the necessary, initial, upfront time that needs to be invested in a fledging initiative that will eventually "pay off," much like the initial money capital 
that has been invested to build the farm infrastructure. The hope is that, down the road, this type of unpaid work will no longer be necessary in order for the rooftop farm to be sustainable. This perspective on unpaid work as an upfront investment of "sweat equity" that will eventually pay off in monetary terms appears to be an example of a non-exploitative form of such work, as it is undertaken voluntarily and knowingly by the two founding farmers. However, it is difficult to consider this as an economic practice that is alternative to a capitalist logic or practice. Instead, it appears consistent with a conventional, market-based logic of economic viability, defined in terms of investment and return.

In contrast, the unpaid work of the interns who work at all three AFIs is characterized more in terms of an "apprenticeship," whereby the intern gives his or her time in exchange for learning a host of farming skills. In this type of unpaid work, there is some sense of a reciprocal relationship of nonmaterial exchange: a moral economy of sorts with transfers of nonmonetary values (Kloppenberg, Hendrickson, \& Stevenson, 1996; Sbicca, 2015). Insofar as this is a voluntary and reciprocal exchange, this form of unpaid work might also be understood as non-exploitative. ${ }^{14}$ However, to the extent that the exchange is not equivalent, with the intern giving more than he or she is getting in return, it is exploitative. Without ways of measuring what is exchanged in some form of commensurate units (such as money), it is difficult to ascertain if an exchange of equivalents is taking place. ${ }^{15}$ Further, if the intern's work is producing

\footnotetext{
${ }^{14}$ It is important to note the problematic nature of the term "voluntary," as it implies that the individual has freely chosen to engage in the activity. However, as we know from feminists' analysis of family relations and historians' analysis of feudal relations, cultural, social, psychological, and economic conditions are often at play in ways that severely impact, constrain, or compel individuals' choices and actions. Indeed, one of Marx's important insights is that in capitalism, a "free worker...must be free in the double sense that as a free individual he can dispose of his labour-power as his own commodity, and that, on the other hand, he has no other commodity for sale, i.e.,...he is free of all the objects needed for the realization of his labour-power" and, therefore, is compelled to sell his ability to work in order to survive (Marx, 1976, pp. 272-273). This element of obligation and
}

goods or services from which the intern supervisor is able to profit, then this too would be an exploitative relationship. While the latter instance is not the case at any of the three AFIs discussed here, this is certainly a possibility in a range of other internship situations on farms, in restaurants, or in small craftfood production.

Finally, unlike interning or apprenticing, a considerable amount of unpaid work is motivated by a myriad of nonmonetary rewards that are not about skill building. For instance, there is the considerable pleasure that some volunteers get from the work itself, the intrinsic rewards of engaging in the actual activity of farming, as well as the rewards of producing something useful, a "use-value." As one volunteer at TFP expressed, "Volunteering at The Food Project is like meditating, a chance to center myself. Something about it feels right.... This work has a beginning, a middle, and an end. And it's immeasurably satisfying to see the results of my labor" (Eli Dan, as quoted in TFP, 2014, pp. 6-7). People also often gain considerable pleasure and joy from giving and contributing to initiatives that they value. Indeed, it is very important to acknowledge and recognize the tremendous generosity of many of those who volunteer at AFIs.

Many volunteers are also motivated by the desire to foster relationships and social connections, as well as a desire to participate in and build community. As another Food Project volunteer commented, "Working with The Food Project has brought me into a meaningful community where I feel useful" (Emily Haselt, as quoted in TFP, 2014,

compulsion with regard to volunteers is at play at both TFP, where many who volunteer do so as a part of an employersponsored "volunteer day," and at CG, insofar as TFP Seed Crew youth "volunteer" on CG farms as a part of their TFP stint and, further, some volunteers have been detainees from the Boston city jail who participate in the Suffolk County Sherriff Department's "Voluntary Work Program" (Connors, 2012).

15 Neoclassical economists resolve this dilemma by assuming that people are free, rational choice agents and, therefore, any actions in which they engage are voluntary and would only be undertaken if the agent receives as much marginal benefit as he or she provides. 
p. 10). In all these situations, this type of unpaid work is indicative of an ethos, politics, and practice that is alternative to for-profit cultures and logics that rely on extrinsic, usually monetized, motivations and reward systems. Further, to the extent that volunteering is motivated by a desire to contribute to endeavors that are seen as "alternative" to the conventional food system, the unpaid work involves a conscious social-change engagement, motivated by a desire to engage in practices that challenge the traditional logics of industrial, market-oriented, capitalist, for-profit businesses. As DeLind (2002) has argued in her discussion of what "civic agriculture" entails, people's time and work are needed to build "community economies," communities that are supportive, healthy, equitable, and environmentally responsible. It may well be that many people volunteer for AFIs for just such reasons.

However, we need to consider the extent to which the food movement's ethics of giving, dedication, commitment, service, and community building might create conditions that enable selfsacrifice and/or self-exploitation, as well as the exploitation of others. This concern was brought to the fore in a conversation with a long-time foodsystem activist who characterized the expectations of working in the alternative food movement more or less as follows: "First you volunteer to prove your dedication. Then you get a stipend which basically means working for less than minimum wage. Then you might eventually get a low-paid job where you can barely make ends meet." He, for one, found it no longer feasible to work in AFIs on these terms. He resigned from his AFI job, and looked into other options for personally rewarding work that contributes to progressive food-system social change but is also more economically sustaining.

Of the three AFIs surveyed here, TFP serves as the most positive example with regard to its reliance upon unpaid work and monetary and inkind donations. For many years, it has been able to realize its three-pronged mission of youth

\footnotetext{
${ }^{16}$ See work by the Community Economies Collective and the Community Economies Research Network for some examples of this (http://www.communityeconomies.org/Home).
}

development, food production and distribution, and community change, while also providing decent paid work for its staff and youth, marshalling the efforts of hundreds of volunteers in a seemingly non-exploitative manner, and garnering monetary donations from individuals and family foundations that fund from one-third to over half of its operations. How generalizable is this model? Clearly, more work needs to be done to think about positive progressive models of organizations that incorporate giving or transfers as a regular form of economic sustenance. ${ }^{16}$ Public radio and faith-based communities come to mind, in that in both cases the cultures of giving that they depend on help constitute them as "public" and as "a community," respectively. In other words, these are communities that are constituted in part through giving. This raises the possibility of creating alternative "public" entities, "public goods," and "public commons" that differ from governmental or state-owned entities. ${ }^{17}$

Yet, even insofar as AFIs are able to sustain themselves through extensive practices of nonexploitative voluntary giving of time and money, we must also think about to what extent such cultures and practices of giving are predicated upon social inequality, with resources redistributed via private transfers from richer (and whiter) households to poorer households, often in communities of color. In other words, AFIs that cultivate giving as a means of sustaining themselves need to avoid charity models of giving and, instead, build supportive communities that recognize social inequities while working to redress them. For TFP, this concern is certainly at play, since many of its monetary donations and much of its volunteer work come from the wealthier communities that surround both Boston and Lynn.

This concern raises yet another important question with regard to AFIs' reliance upon volunteer labor. What are the circumstances that enable people to engage voluntarily in all of this unpaid food work? Certainly, in many communities, a lot of unpaid food work involves self-provisioning via

\footnotetext{
${ }^{17}$ See Loh (2015) for a discussion of how community land trusts are being used to refashion a "commons" in cities such as Boston, Detroit, and Philadelphia.
} 
growing your own, processing your own, and cooking your own food. In Boston, however, growing your own food is not very significant, with processing and preparing your own food more significant (since 63 percent of food expenditures are for food consumption in the home, more than the national average of 59 percent) (Bureau of Labor Statistics, 2015). Yet, in the case of the AFIs under consideration here, the unpaid food work that takes place is not for self-provisioning. Instead, it is undertaken for the myriad reasons outlined above: as an investment that will hopefully pay off in the future, as a skill-building apprenticeship, or as a contribution of time that provides multiple intrinsic benefits, both individual and social. And yet, since the work of producing food is both physically demanding and fairly time-intensive (which is why most people with living wage jobs increasingly pay others to do it), we must ask, who has the time to garden or to volunteer in urban agriculture initiatives? Who is able to work as an intern at HGF, CG, or TFP for free or for a relatively small stipend? It may be that many low-income people are so resource-strapped that it is often a struggle for them to offer significant amounts of time or money as volunteers or donors in AFIs. How, then, to build community economies where the transfers and giving that occur are on the basis of equitable reciprocity? How is it possible to afford more people the support they need to allow them to take the time to volunteer or to have the resources to make monetary donations to the community food system initiatives they support?

To the extent that alternative food initiatives depend upon volunteer time and unpaid work, these are crucial questions. Yet, they raise significant challenges for small, individual AFIs to address on their own, since enabling such support entails countervailing ever-widening economic inequalities in the U.S. As others have noted (Myers \& Sbicca, 2015; Sbicca, 2015), while individual AFIs may be able to engage in and foster progressive alternative economic practices within their own enterprises and with those entities with whom they partner, to enable broader equitable economic practices within the communities in which AFIs work, AFIs need to engage in more extensive coordination and collaboration across
AFIs, with the larger "good food movement," and with other progressive social movements to support effective municipal, state, and nationwide policies that promote economic equality.

\section{Acknowledgements}

I would like to thank my undergraduate research assistant, Autumn Beaudoin, for help in compiling data from The Food Project's IRS 990 forms. Thanks also to Ivor Kaklins, Valerie Leiter, and Niloufer Sohrabji, as well as to the JAFSCD reviewers for their thoughtful and substantive comments on earlier drafts of this article.

\section{References}

Alkon, A. H. (2014). Food justice and the challenge to neoliberalism. Gastronomica: The Journal of Food and Culture, 14(2), 27-40. http://dx.doi.org/10.1525/gfc.2014.14.2.27

Alkon, A. H., \& Agyeman, J. (2011). Cultivating food justice. Race, class, and sustainability. Cambridge, Massachusetts: MIT Press.

Allen, P. (2010). Realizing justice in local food systems. Cambridge Journal of Regions, Economy and Society, 3, 295-308. http://dx.doi.org/10.1093/cjres/rsq015

Amin, A. (Ed.). (2009). The social economy: International perspectives on economic solidarity. London: Zed Books.

Anguelovski, I. (2014). Neighborhood as refuge: Community reconstruction, place remaking, and environmental justice in the city. Cambridge, Massachusetts: The MIT Press. http://dx.doi.org/10.7551/mitpress/97802620269 25.001.0001

Annear, S. (2012). Boston to get very first roof-top farm. Will be second largest in the world. BostInno. Retrieved from http://bostinno.streetwise.co/ 2012/11/14/higher-ground-farm-boston-roof-top/

Ballamingie, P., \& Walker, S. L. (2013). Field of dreams: Just Food's proposal to create a community food and sustainable agriculture hub in Ottawa, Ontario. Local Environment, 18(5), 529-542. http://dx.doi.org/10.1080/13549839.2013.787975

Barndt, D. (1999). Women working the NAFT A food chain: Women, food and globalization. Toronto, Canada: Second Story Press.

Biewener. C. (2001). The promise of Finance: Banks and community development. In J. K. Gibson-Graham, S. Resnick, and R. Wolff (Eds.). Re/presenting class: Essays in postmodern Marxism, (pp. 131-157). Durham, North Carolina: Duke University Press. 
Biewener. C. (2006). France and Québec: The progressive visions embodied in different social economy traditions. In B. J. Clary, W. Dolfsma \& D. M. Figart (Eds.), Ethics and the market: Insights from social economics (pp. 126-139). London, England: Routledge.

Boston Design Center (BDC). (n.d.). Boston Design Center. Retrieved on March 9, 2015, from http://bostondesign.com/

Boyer, M. (2013). Boston's Higher Ground Farm will be the second-biggest rooftop farm in the world. Inhabitat. Retrieved from http://inhabitat.com/ bostons-higher-ground-farm-will-be-the-secondbiggest-rooftop-farm-in-the-world/

Bureau of Labor Statistics. (2015). Consumer Expenditure Survey, Tables 1800 and 3002. Retrieved from http://www.bls.gov/cex/2014/combined/region.p df and http://www.bls.gov/cex/2013/msas/norteast.pdf

Cadieux, K. V., \& Slocum, R. (2015). What does it mean to do food justice? Journal of Political Ecology 22, $1-$ 26.

City Growers (CG). (2013). Thanks to all our supporters. Retrieved on January 18, 2014, from https:/ / citygrowers.wordpress.com/2013/08/13/t hanks-to-all-our-supporters/

CG. (n.d.-a). Mission/Vision. Retrieved on January 18, 2014 from https://citygrowers.wordpress.com/ mission-vision/

CG. (n.d.-b). Urban farming conference. Panel 9: Youth and Urban farming. Retrieved on March 8, 2015, from https:/ / citygrowers.wordpress.com/urbanfarming-conference/panel-9-youth-and-urbanfarming/

Community Economies Collective. (2001). Imagining and enacting noncapitalist futures. Socialist Review, 28(3-4), 93-105.

Connelly, S., Markey, S., \& Roseland, M. (2011). Bridging sustainability and the social economy: Achieving community transformation through local food initiatives. Critical Social Policy, 31(2), 308-324. http://dx.doi.org/10.1177/0261018310396040

Connors, M. (2012, April 4). Hampshire College. Presidential Lecture Series [Video File]. Retrieved from https://www.youtube.com/watch?v=id2CKNgDm $\underline{\text { mo\&feature }=\text { player embedded }}$
Conservation Law Foundation \& CLF Ventures, Inc. (CLF). (2012, July). Growing green: Measuring benefits, overcoming barriers, and nurturing opportunities for urban agriculture in Boston. Boston, Massachusetts: Authors. http://www.clf.org/our-work/healthycommunities/farm-and-food-initiative/food-workin-massachusetts/

Dacheux, E., \& Goujon, D. (2011). The solidarity economy: An alternative development strategy? International Social Science Journal, 62(203204), 205-215. http://dx.doi.org/10.1111/j.14682451.2011.01804.x

DeLind, L. B. (2002). Place, work, and civic agriculture: Common fields for cultivation. Agriculture and Human Values, 19(3), 217-224.

Dudley Street Neighborhood Initiative (DSNI). (n.d.-a). History. Retrieved on 8/26/15 from http://www.dsni.org/dsni-historic-timeline/

DSNI. (n.d.-b). Dudley Neighbors, Inc. Retrieved on 8/26/15 from http://www.dsni.org/dudleyneighbors-inc/

DuPuis, E. M., \& Goodman, D. (2005). Should we go "home" to eat?: Toward a reflexive politics of localism. Journal of Rural Studies, 21(3), 359-371. http://dx.doi.org/10.1016/j.jrurstud.2005.05.011

Food Chain Workers Alliance. (2012, June 6). The hands that feed us. Challenges and opportunities for workers along the food chain. Los Angeles. Retrieved from http://foodchainworkers.org/wp-content/ uploads/2012/06/Hands-That-Feed-Us-Report.pdf

Galt, R. E. (2013). The moral economy is a doubleedged sword: Explaining farmers' earnings and selfexploitation in community-supported agriculture. Economic Geography, 89(4), 341-365. http://dx.doi.org/10.1111/ecge.12015

Gibson-Graham, J. K. (2006). A postcapitalist politics. Minneapolis: University of Minnesota Press.

Gibson-Graham, J. K. (2008). Diverse economies: Performative practices for other worlds. Progress in Human Geography, 32(5), 613-663. http://dx.doi.org/10.1177/0309132508090821

Glasmeier, A. (2016). Living wage calculation for Suffolk County, Massachusetts. Retrieved from http://livingwage.mit.edu/places/2502507000

Goodman, M. K., Maye, D., \& Holloway, L. (2010). Ethical foodscapes? Premises, promises, and possibilities. Environment and Planning A, 42(8), 1782-1796. http://dx.doi.org/10.1068/a43290 
Gottlieb, R., \& Joshi, A. (2010). Food justice. Cambridge, Massachusetts: MIT Press.

Gray, M. (2014). Labor and the locavore. The making of a comprehensive food ethic. Berkeley: University of California Press.

Guthman, J. (2004). Agrarian dreams: The paradox of organic farming in California. Berkeley: University of California Press.

Hansman, H. (2014, April 16). How new legislation in Boston gave fresh life to urban farms. Modern Farmer. Retrieved from http://modernfarmer.com/2014/04/legislationboston-article-89-urban-farms /

Harris, P. \& Lyon, D. (2013, February 1). Companies cultivating urban-farming initiatives. The Boston Globe. Retrieved from http://www.bostonglobe.com/lifestyle/2013/ 02/01/conference-focus-urban-farming-city/ 0NpBjnqocbvBtNK6xeCt2K/story.html

Hassanein, N. (2003). Practicing food democracy: A pragmatic politics of transformation. Journal of Rural Studies, 19(1), 77-86. http://dx.doi.org/10.1016/S0743-0167(02)00041-4

Higher Ground Farm. (n.d.). Higher Ground Farm Facebook page. Retrieved on January 15, 2014, https://www.facebook.com/highergroundfarm/inf o?tab=page info

Hinrichs, C. (2000). Embeddedness and local food systems: Notes on two types of direct agricultural market. Journal of Rural Studies, 16(3), 295-303. http://dx.doi.org/10.1016/S0743-0167(99)00063-7

Holmes, S. (2013). Fresh fruit, broken bodies. Migrant farmworkers in the United States. Berkeley: University of California Press.

Holt, S. (2013, March 12). 9 stories high and rising: Boston on the brink of first rooftop farm. Takepart. Retrieved from http://www.takepart.com/article/ 2013/03/11/9-stories-rooftop-farmers-breakingnew-ground-boston

Internal Revenue Service (IRS). (2004). Form 990: Return of organization exempt from income tax: The Food Project, Inc. Copy in possession of author.

IRS. (2005, 2006, 2007, 2008, 2009, 2010, 2011, 2012, 2013). Form 990: Return of organization exempt from income tax: The Food Project, Inc. Retrieved from the Economic Research Institute database: http://207.153.189.83/EINS/043262532/0432625 32_2005_02B9C239.PDF
http://207.153.189.83/EINS/043262532/0432625 322006 042EE6B1.PDF

http://207.153.189.83/EINS/043262532/0432625 322007 04BFC4DB.PDF

http://207.153.189.83/EINS/043262532/0432625 322008 05BCABFC.PDF

http://207.153.189.83/EINS/043262532/0432625 32_2009_069F82BB.PDF

http://207.153.189.83/EINS/043262532/0432625 $32 \quad 2010 \quad 08099 \mathrm{a} 0 \mathrm{c} . \mathrm{PDF}$

http://207.153.189.83/EINS/043262532/0432625

$32 \quad 2011$ 08f9f4ef.PDF

http://207.153.189.83/EINS/043262532/0432625

$32 \quad 2012$ 0a0bf14b.PDF

http://207.153.189.83/EINS/043262532/0432625

322013 0b1ce0dc.PDF

Jarosz, L. (2007). The city in the country: Growing alternative food networks in metropolitan areas. Journal of Rural Studies, 24(3), 231-244. http://dx.doi.org/10.1016/j.jrurstud.2007.10.002

Kahn, J. (2013, April 30). Coming to a rooftop near you. The Boston Globe. Retrieved from http://www.bostonglobe.com/lifestyle/fooddining/2013/04/30/ coming-rooftop-nearyou/9PMEeoQPCIrWBcWbCqAmhK/story.html

Kloppenberg, J., Hendrickson, J., \& Stevenson, G. W. (1996). Coming into the foodshed. Agriculture and Human Values, 13(3), 33-42. http://dx.doi.org/10.1007/BF01538225

Landry, C. (2013, September 6). Supply chain: Up on the roof with Higher Ground Farm [Blog post]. Boston Magazine. Retrieved from http://www.boston magazine.com/restaurants/blog/2013/09/06/supp ly-chain-up-on-the-roof-with-higher-ground-farm/

Liu, Y. Y. (2012). Good food and good jobs for all: Challenges and opportunities to advance racial and economic equity in the food system. Oakland, California: Applied Research Center. Retrieved from https://www.race forward.org/research/reports/food-justice

Lo, J. (2014). Social justice for food workers in a foodie world. Journal of Critical Thought and Praxis, 3(1), 1-22.

Loh, P. (2015). Urban farming, one vacant lot at a time. Yes!, Winter, 34-39.

Loh, P. \& Shear, B. (2015). Solidarity economy and community development: Emerging cases in three Massachusetts cities. Community Development, 46(3), 244-260. http://dx.doi.org/10.1080/15575330.2015.1021362 
Lyson, T. A. (2007). Civic agriculture and the North American food system. In C. C. Hinrichs and T. A. Lyson (Eds.), Remaking the North American Food System: Strategies for Sustainability, (pp. 19-32). Lincoln: University of Nebraska Press.

Marx, K. (1976). Capital. Volume One. New York: Random House.

McClintock, N. (2014). Radical, reformist, and gardenvariety neoliberal: Coming to terms with urban agriculture's contradictions. Local Environment, 19(2), 147-171.

http://dx.doi.org/10.1080/13549839.2012.752797

Myers, J. S., \& Sbicca. J. (2015). Bridging good food and good jobs: From secession to confrontation within alternative food movement politics. Geoforum, 61, $17-26$.

http://dx.doi.org/10.1016/i.geoforum.2015.02.003

New Entry Sustainable Farming. (n.d.). New entry sustainable farming project. Retrieved on August 26, 2015, from http://nesfp.org/

Rajewski, G. (2011). A growth industry? Edible Boston. Retrieved from http://www.edibleboston.com/agrowth-industry/

Ramey, E. (2014). Class, gender and the American family farm in the 20th century. London: Routledge.

Reynolds, D. B. (2002). Taking the high road: Communities organize for economic change. Armonk, New York: M.E. Sharpe.

Sachs, C., Allen, P., Terman, R., Hayden, J., \& Hatcher, C. (2014). Front and back of the house: Sociospatial inequalities in food work. Agriculture and Human Values, 31(1), 3-17. http://dx.doi.org/10.1007/s10460-013-9445-7

Sbicca, J. (2015). Food labor, economic inequality, and the imperfect politics of process in the alternative food movement. Agriculture and Human V alues,
32(4), 675-687. http://dx.doi.org/10.1007/s10460015-9582-2

Shemkus, S. (2014, June 21). Urban farming takes root. The Boston Globe. Retrieved from https://www.bostonglobe.com/business/2014/06 $\angle 21 /$ urban-farming-takes-root/IoeiZucFBdu2b9

HRWYZIVO/story.html

The Food Project (TFP). (2013). 2012-2013 Annual report. Growing hand in hand. Retrieved from http://thefoodproject.org/sites/default/files/TFP 2012-2013 Annual\%20Report \%20FINAL.pdf

TFP. (2014). 2013-2014 Annual report. Retrieved from http://issuu.com/thefoodproject/docs/food proje ct_2014_ar

TFP. (n.d.-a). About us. Retrieved on March 8, 2015, from http://thefoodproject.org/about

TFP. (n.d.-b). Community programs. Retrieved on March 8, 2015, from http://thefoodproject.org/community-programs

Trustees of Reservations. (n.d.) LinkedIn profile. Retrieved on September 19, 2015, from https://www.linkedin.com/groups/1855196/ profile

Wakefield, J. (2014). Urban farmers take to the roof in Boston. Vermont Quarterly. University of Vermont. Retrieved from http://www.uvm.edu/vq/?Page= news\&storyID $=\% 2017885 \&$ category $=$ vqafocus

Watts, D. C. H., Ilbery, B., \& Maye, D. (2005). Making reconnections in agro-food geography: Alternative systems of food provision. Progress in Human Geography, 29(1), 22-40. http://dx.doi.org/10.1191/0309132505ph526oa

Wilson, A.D. (2013). Beyond alternative: Exploring the potential for autonomous food spaces. Antipode 45(3), 719-737. http:/ / dx.doi.org/ 10.1111/j.1467-8330.2012.01020.x 